\title{
Late Classic Climate Change and Societal Response in the Maya Lowlands ${ }^{1}$
}

\author{
Benjamin Keenan, McGill University
}

\begin{abstract}
This article summarises the scientific methods used to study past climate in the Maya Lowlands. It also provides an overview of the strategies employed by the ancient Maya to adapt to natural climate change and address issues associated with their growing population. The Maya response to these challenges, including to severe droughts between 800 and $1000 \mathrm{CE}$, culminated in a societal restructuring sometimes referred to as "the Classic collapse." The story of the Lowland Maya may serve as a "lesson" going forward, as we confront similar issues in the twenty-first century, e.g., food insecurity, water scarcity, pandemics, and waste management, all in the context of anthropogenic climate change. The ancient Maya experience might provide useful insights, given that the effects of modern-day climate change are already being felt.
\end{abstract}

Keywords: Climate Change; Lowland Maya; Palaeoclimatology; Climate Adaptation.

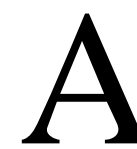

nthropogenic climate change is now viewed as an existential threat that requires society to question how we live, and how to use resources more sustainably. The increase in atmospheric $\mathrm{CO}_{2}$, from about $280 \mathrm{ppm}$ prior to the Industrial Revolution (ca. 1850) to approximately 411 ppm today ${ }^{2}$ has led to an increase in the number and severity of extreme weather events - extensive and frequent forest fires, and coastal flooding due to rising sea levels. Numerous ancient societies were also confronted with the effects of climate change. In the absence of instrumental and/or anecdotal evidence, scholars use a combination of archaeological, geochemical and biological tools to gain insights into how climate changed through time and how ancient people responded to those changes. This article provides an overview of the way in which the Lowland Maya of Mesoamerica were impacted by climate change and how they chose to respond to it.

\section{Climate Change and Ancient Societies}

During the Holocene era, the epoch that began approximately 11,500 years ago - from the end of the last glacial period until today - climate is thought to have been controlled by orbital forcing of solar insolation, ocean circulation, ocean-atmosphere interactions, and solar activity variability. ${ }^{3}$ Holocene climate was previously thought to have been stable, but we now understand that considerable climate variability was in fact the norm. Dry periods in prehistory have been correlated with times of social upheaval, which led in some cases to large-scale restructuring of society, this period of chaos is sometimes referred to as a "collapse." Numerous societies were affected by climate variability, including the Akkadians in Mesopotamia, the Khmer in Cambodia, and the Lowland Maya of southern

1. Acknowledgements: Thank you to Claire Marie Guimond, Mark Brenner, Bjorn Sundby and the peer-reviewers for their comments and feedback.

2. Pieter Tans and Ralph Keeling, "Trends in Atmospheric Carbon Dioxide," Global Monitoring Laboratory, accessed March 30, 2020, www.esrl.noaa.gov/gmd/ccgg/trends/.

3. Peter B. DeMenocal, "Cultural Responses to Climate Change During the Late Holocene," Science 292, no. 5517 (April 2001): 667-673, https://doi.org/10.1126/science.1059287. 
Mexico and northern Central America. ${ }^{4}$ This article focuses on the latter to illustrate the complex relationship between climate, environment and society.

\section{Background of the Lowland Maya}

The Lowland Maya were an ancient civilisation that experienced profound transformation following a period of considerable climate change. ${ }^{5}$ They had a complex organizational structure that arose in the tropical forests of southern Mexico and northern Central America. Their civilization is known for its unique architecture, beautiful polychrome pottery, profound knowledge of astronomy and mathematics, and their highly developed written language and calendar systems. ${ }^{6}$ The Lowland Maya inhabited the Yucatán Peninsula, a region comprised almost entirely of low-lying karst bedrock. In the northern part of the lowlands, cenotes (sinkholes), caves and wells provided access to the shallow water table, whereas in the south, where the water table is much deeper below the land surface, rivers, lakes, bajos, and reservoirs were the primary sources of drinking water. The Maya Lowlands are characterised by intense seasonal rainfall, with a dry season from January to May, and a rainy season from late May / early June until early January, although the timing of the onset of rains can vary considerably from year to year. ${ }^{7}$ Rainfall is also distributed unevenly across the region. The northwest coast of the Yucatan Peninsula is very dry, but annual rainfall increases southward.

The Lowland Maya were affected by multiple environmental (e.g., droughts, floods, soil erosion) and socio-political (population growth, disease, internecine warfare) factors at different times throughout their history. ${ }^{8}$ Two overarching questions are pertinent to the Maya context: 1 ) how did the ancient Lowland Maya respond to documented climate variations? and 2) how did this complex human society alter their tropical forest environment over thousands of years? Major time periods along with their respective human cultural developments are shown in Table 1. To understand how Maya cultural development was related to environmental changes, we must first uncover what the past environment looked like. We will now move on to discuss the techniques used to reconstruct the palaeo-environment.

Table 1. Maya chronology time periods ${ }^{9}$

\begin{tabular}{|l|l|l|}
\hline Period & Estimated dates & Major cultural developments \\
\hline Postclassic & $900 / 1100-1500 \mathrm{CE}$ & Reformulation and revival of states \\
\hline Terminal Classic & $800-900 / 1100 \mathrm{CE}$ & Decline and transformation of states \\
\hline Late Classic & $600-800 \mathrm{CE}$ & Apogee of lowland states \\
\hline Early Classic & $250-600 \mathrm{CE}$ & Expansion of lowland states \\
\hline
\end{tabular}

4. See: H. Weiss et al., "The Genesis and Collapse of Third Millennium North Mesopotamian Civilization," Science 261, no. 5124 (1993): 995-1004, https://doi.org/10.1126/science.261.5124.995; Brendan M. Buckley et al., "Climate as a Contributing Factor in the Demise of Angkor, Cambodia," Proceedings of the National Academy of Sciences of the United States of America 107, no. 15 (April 2010): 6748-6752, https://doi.org/10.1073/pnas.0910827107; David A. Hodell, Jason H. Curtis, and Mark Brenner, "Possible Role of Climate in the Collapse of Classic Maya Civilization," Nature 375, no. 6530 (June 1995): 391-394, https://doi.org/10.1038/375391a0.

5. Hodell, Curtis, and Brenner, "Possible Role of Climate," 391-394.

6. Robert J. Sharer and Loa P. Traxler, The Ancient Maya, Sixth Edition (Stanford, California: Stanford University Press, 2006): 4-5.

7. Lisa J. Lucero, Joel D. Gunn, and Vernon L. Scarborough, "Climate Change and Classic Maya Water Management," Water 3, no. 2 (December 2011): 479-494, https://doi.org/10.3390/w3020479.

8 . James J. Aimers, "What Maya Collapse? Terminal Classic Variation in the Maya Lowlands," Journal of Archaeological Research 15, no. 4 (September 2007): 329-377, https://doi.org/10.1007/s10814-007-9015-x.

9. Sharer and Traxler, The Ancient Maya: 98. 


\begin{tabular}{|l|l|l|}
\hline Terminal Preclassic & $100-250 \mathrm{CE}$ & Decline and transformation of states \\
\hline Late Preclassic & $400 \mathrm{BC}-100 \mathrm{CE}$ & Initial states \\
\hline Middle Preclassic & $1000-400 \mathrm{BCE}$ & Growth in socioeconomic complexity \\
\hline Early Preclassic & $2000-1000 \mathrm{BCE}$ & Initial complex societies \\
\hline Archaic & $8000-2000 \mathrm{BCE}$ & Settled communities and agriculture \\
\hline Paleo-Indian or Lithic & $12,000 / 20,000-8,000 \mathrm{BCE}$ & Initial settlement of the Americas \\
\hline
\end{tabular}

\section{Inferring Past Climate and Population}

Palaeoclimate and palaeoenvironmental inferences rely on the measurement of multiple proxies found in natural archives (e.g., lake sediments, cave speleothems [stalagmites], tree rings, ice cores, etc.). Proxies are substitute variables that are analysed when it is not possible to directly measure a variable of interest, for instance past temperature. Palaeoclimate/palaeoenvironment archives are thus used to establish baselines, pre-disturbance conditions, and to explore how ancient societies responded to past climate and environmental changes. Proxy variables may include any of the following components: stable isotopes $\left(\delta^{13} \mathrm{C}\right.$ and $\left.\delta^{18} \mathrm{O}\right)$ of carbonate microfossils (snails, ostracods, foraminifera) and speleothems, gas composition in ice core bubbles, tree ring width measurement, analysis of diatoms, charcoal, pollen, and more. Data on past climate and environment in the Maya Lowlands have been obtained largely from speleothems as well as lake and marine sediment cores. ${ }^{10}$ Lake sediments incorporate a variety of environmental materials such as pollen grains, diatoms, charcoal, carbonate fossils and diagnostic organic molecules (biomarkers). Biomarkers are sourced from specific, identifiable organisms. They are resistant to degradation and accumulate in sediments of both marine and lake basins. Lake deposits integrate materials from local and regional sources, these accumulated sediment sequences contain continuous, high-resolution records of past environmental change. ${ }^{11} \mathrm{~A}$ lake sediment core can thus provide information about changing conditions over long time periods.

Most palaeoclimate studies in the Maya region have relied on the measurement of oxygen isotopes ${ }^{12}$ in the carbonate shells of sedimented lacustrine snails and ostracods. Such studies provide information about past hydroclimate conditions, i.e. shifts in the relation between evaporation and precipitation (E/P). When lake water evaporates during dry times, the light stable isotope of oxygen $\left({ }^{16} \mathrm{O}\right)$ is preferentially lost as it evaporates faster, and the heavy stable isotope $\left({ }^{18} \mathrm{O}\right)$ is preferentially left behind in the lake. During drier periods, i.e. when the ratio of evaporation to rainfall is high, there is thus relatively more ${ }^{18} \mathrm{O}$ in the lake water (the ratio of ${ }^{18} \mathrm{O}$ to ${ }^{16} \mathrm{O}$ is higher) in comparison to wetter periods. Organisms such as snails and ostracods preserve in their calcium carbonate $\left(\mathrm{CaCO}_{3}\right)$ shells a record of the oxygen isotopic composition of the lake water in which they lived. The shells are incorporated into the accumulating sediment, thereby preserving a record of long-term shifts in E/P. For such measures to be useful palaeoclimate proxies however, a number of conditions must be met. First,

10. Michael F. Rosenmeier et al., "A 4000-Year Lacustrine Record of Environmental Change in the Southern Maya Lowlands, Petén, Guatemala," Quaternary Research 57, no. 2 (Febuary 2002): 183-190, https://doi.org/10.1006/ qres.2001.2305; Andreas D. Mueller et al., "Recovery of the Forest Ecosystem in the Tropical Lowlands of Northern Guatemala after Disintegration of Classic Maya Polities," Geology 38, no. 6 (June 2010): 523-526, https://doi.org/10.1130/G30797.1; Martín Medina-Elizalde et al., "High-Resolution Speleothem Record of Precipitation from the Yucatan Peninsula Spanning the Maya Preclassic Period," Global and Planetary Change 138 (October 2016): 93-102, https://doi.org/10.1016/j.gloplacha.2015.10.003.

11. Nathalie Dubois and Jérémy Jacob, "Molecular Biomarkers of Anthropic Impacts in Natural Archives: A Review," Frontiers in Ecology and Evolution 4, (August 2016): 1-16, https://doi.org/10.3389/fevo.2016.00092.

12. Kees Nooren et al., "Climate Impact on the Development of Pre-Classic Maya Civilization," Climate of the Past Discussions 14, no. 8 (August 2018): 1253-1273, https://doi.org/10.5194/cp-2018-15. 
it is preferable to conduct such studies in hydrologically "closed-basin" lakes, in which nearly all water is lost to evaporation, and shifts in E/P dramatically alter the lake water balance, that is the oxygen isotopic composition of the lake water. Lakes that lose a substantial fraction of their volume to outflows will not be sensitive recorders, isotopically, of changes in E/P. ${ }^{13}$ Second, in some lakes, sediments contain little or no biogenic carbonate material on which to measure the oxygen isotope composition, so it is wise to seek lakes with carbonate-rich sediments.

The carbonate in cave speleothems also preserves a record of oxygen isotopic composition, and stalagmites can frequently be dated very accurately using the radiometric dating uranium/thorium method, where the abundance of a radioactive isotope (uranium 234) and its decay product (thorium 230) can be used with known decay rates to determine the age of a material. ${ }^{14}$ Speleothem oxygen isotope records are interpreted in a way similar to lake sediment records. At cave sites, water infiltrates into the ground above the cave, drips from the roof onto the floor, and degases carbon dioxide, thereby causing carbonate deposits to form. The growing stalagmite records the oxygen isotopic composition of the drip water that originated outside the cave which is then related to the amount of rainfall. ${ }^{15}$ Speleothems have yielded some of the highest-resolution records of past climate change in the Maya Lowlands. Speleothems provides high temporal resolution of palaeoclimate records which enables scholars to make reliable correlations between past climate changes and documented historical events from documented archaeological records. Well-dated, high temporal resolution, speleothem-derived palaeoclimate records are even capable of detecting droughts of smaller magnitude and shorter duration. They also allow for correlations with broader climate patterns, such as changes in the frequency of El Niño events and shifts in the position of the Intertropical Convergence Zone. ${ }^{16}$

Some lipid biomarkers, such as those produced in the leaves of terrestrial plants, are equally valuable proxies for past climate conditions. Leaf waxes are synthesised by plants to inhibit water loss, provide protection from UV light and disease, and are used as chemical barriers. ${ }^{17}$ The relative abundances of the stable isotopes of hydrogen (protium $\left[{ }^{1} \mathrm{H}\right]$ and deuterium $\left[{ }^{2} \mathrm{H}\right]$ ) are understood in relation to the hydrological cycle. Plants use water in the environment as a hydrogen source, thus the hydrogen isotope composition of plant wax lipids is controlled by the composition of the water used during growth. The hydrogen isotopic composition $(\delta \mathrm{D})$ of rainwater is controlled by the temperature of condensation, the amount of precipitation, the travel history of the air mass, and the evaporation of the water. When water vapour condenses, the rain is enriched in heavier hydrogen isotope which is relative to the vapour, and the remaining vapour becomes depleted in deuterium. The $\delta \mathrm{D}$ in the tropics is largely determined by the amount of rain. With increased rainfall, the $\delta \mathrm{D}$ is lower. Plants take up water from the soil, whose isotope composition represents an amount-weighted average of precipitation inputs, although this value can be altered by surface evaporation. This water is used in the biosynthesis of plant waxes, thereby preserving the hydrogen isotopic composition. ${ }^{18}$

13. Martín Medina-Elizalde et al., "High Resolution Stalagmite Climate Record from the Yucatán Peninsula Spanning the Maya Terminal Classic Period," Earth and Planetary Science Letters 298, 1-2 (September 2010): 255-262, https://doi.org/10.1016/i.eps1.2010.08.016.

14. Peter M.J. Douglas et al., "Impacts of Climate Change on the Collapse of Lowland Maya Civilization," Annual Review of Earth and Planetary Sciences 44, no. 1 (June 2016): 613-645, https://doi.org/10.1146/annurev-earth-060115012512.

15. Frank McDermott, "Palaeo-Climate Reconstruction from Stable Isotope Variations in Speleothems: A Review," Quaternary Science Reviews 23, no. 7-8 (April 2004): 901-918, https://doi.org/10.1016/j.quascirev.2003.06.021.

16. Douglas J. Kennett et al., "Development and Disintegration of Maya Political Systems in Response to Climate Change," Science 338, no. 6108 (November 2012): 788-791, https://doi.org/10.1126/science.1226299.

17. Aaron F. Diefendorf and Erika J. Freimuth, "Extracting the Most from Terrestrial Plant-Derived n-Alkyl Lipids and Their Carbon Isotopes from the Sedimentary Record: A Review," Organic Geochemistry 103 (January 2017): 1-21, https://doi.org/10.1016/j.orggeochem.2016.10.016.

18 . Dirk Sachse et al., "Molecular Paleohydrology: Interpreting the Hydrogen-Isotopic Composition of Lipid Biomarkers from Photosynthesizing Organisms," Annual Review of Earth and Planetary Sciences 40, no. 1 (May 2012): 
Plant waxes are ubiquitous in lake sediments, whereas, as previously mentioned, carbonate shells of aquatic organisms are not found in all lakes. Plant waxes also record the stable carbon isotope composition $\left(\delta^{13} \mathrm{C}\right)$ of catchment vegetation, which reflects whether the plants used the $\mathrm{C}_{3}$ (most forest trees) or $\mathrm{C}_{4}$ (most tropical grasses) photosynthetic pathway, and can therefore be used to indicate past vegetation type. ${ }^{19}$ The Maya cleared $\mathrm{C}_{3}$ trees to make way for maize agriculture. Corn is a $\mathrm{C}_{4}$ plant, and therefore plant wax carbon isotopes can provide an indication of the relative cover of forest versus savannah and agricultural plots. Plant waxes have been analysed in many places around the world, ${ }^{20}$ including the Maya Lowlands, as well as supplement palaeoclimate information derived from other proxies. ${ }^{21}$ Plant waxes can contribute to better understand the overarching questions about Maya prehistory: 1) How did the relation between evaporation and precipitation change in the MayaLowlands, and how might it have affected ancient Maya culture? and 2) How did the ancient Maya alter the vegetation in the region?

Pollen of flowering plants and fern spores are dispersed by wind and animals (e.g. insects, bats) and are also used to infer palaeoenvironmental change. Pollen assemblages might not be appropriate for inferring climate change during the peak periods of Maya occupation, as human-induced disturbances in pollen assemblages during those intervals likely obscured any signal related to climate change. ${ }^{22}$ However, the pollen record from lake sediment cores provides invaluable information about past vegetation change. For instance, Barbara Leyden presented a 36,000-year record of climate and environmental change in the northern lowlands of Guatemala, using pollen data from a lake sediment core. ${ }^{23}$ The record shows that during the Pleistocene period the climate of the region was colder and dryer, but at the beginning of the Holocene period it became warmer and wetter. Until about 2000 BCE, low numbers of people inhabited the Maya Lowlands region suggesting that pollen records from before that time faithfully recorded the influence of climate on the regional vegetation. The Holocene pollen record began to change ca. $1500 \mathrm{BCE}$ as the human population grew and people modified the landscape. Slash-and-burn agriculture increased the need for trees leading to greater forest clearance which is documented by the relative decline in forest pollen types, an increase in charcoal deposition, and the appearance of agricultural pollen types. Widespread deforestation was accompanied by rapid deposition in local lakes of a thick, erosional, fine-grain clay level, sometimes referred to as the "Maya Clay." 24 Maize pollen is present in the upper levels of the Maya clay at Lake Salpeten. As deforestation continued, pine and oak pollen were also transported into the lake. Various pollen assemblages show changing land usage during the Late Preclassic, Early Classic, Late Classic, Late Classic collapse, and

221-249, https://doi.org/10.1146/annurev-earth-042711-105535.

19. Diefendorf and Freimuth, "Extracting the Most from Terrestrial," 1-21.

20. Sarah J. Feakins and Alex L. Sessions, "Controls on the D/H Ratios of Plant Leaf Waxes in an Arid Ecosystem," Geochimica et Cosmochimica Acta 74, no. 7 (April 2010): 2128-2141, https://doi.org/10.1016/j.gca.2010.01.016; Sarah J. Feakins, "Pollen-Corrected Leaf Wax D/H Reconstructions of Northeast African Hydrological Changes during the Late Miocene," Palaeogeography, Palaeoclimatology, Palaeoecology 374 (March 2013): 62-71, https://doi.org/10. 1016/j.palaeo.2013.01.004; E. Niedermeyer et al., "Southwestern African Climate Change during Heinrich Stadial 1 Inferred from Plant Wax $\delta 13 \mathrm{C}$ and $\Delta$ D from Rock Hyrax Middens," Quaternary International 404 (June 2016): 202, https://doi.org/10.1016/j.quaint.2015.08.181.

21. Peter M. J. Douglas et al., "Drought, Agricultural Adaptation, and Sociopolitical Collapse in the Maya Lowlands," Proceedings of the National Academy of Sciences 112, no. 18 (May 2015): 5607-5612, https://doi.org/10. 1073/pnas.1419133112.

22. Simon Schüpbach et al., "Combining Charcoal Sediment and Molecular Markers to Infer a Holocene Fire History in the Maya Lowlands of Petén, Guatemala," Quaternary Science Reviews 115, no.1 (May 2015): 123-131, https://doi.org/10.1016/j.quascirev.2015.03.004.

23. Barbara W. Leyden, "Pollen Evidence for Climatic Variability and Cultural Disturbance in the Maya Lowlands," Ancient Mesoamerica 13, no. 1 (January 2002): 85-101, https://doi.org/10.1017/S0956536102131099.

24. Leyden, "Pollen Evidence for Climatic Variability," 85-101, https://doi.org/10.1017/S0956536102131099. 
the Postclassic periods. A change that was also visible during the post-Maya period with the recovery of forests. ${ }^{25}$

Palaeoclimate data provides an important context for interpreting changes in the archaeological record such as the indication that there was considerable climate variability throughout the period of the late Holocene occupation, and that a series of droughts occurred between 800 and $1000 \mathrm{CE}$, coinciding with archaeological evidence for social upheaval and cultural disintegration. ${ }^{26}$ Palaeoclimate and palaeoecological records have a great deal to offer in terms of data and can help provide additional information to compliment existing archaeological records. The development of new approaches such as using the oxygen-17 isotopic composition of water trapped in gypsum to infer palaeohydrology, has allowed researchers to estimate the quantitative reduction of past rainfall ${ }^{27}$ and is leading to more refined palaeoclimate reconstructions. ${ }^{27}$ In addition, allowing the application of novel methods, in determining past population change, to be independent of archaeological evidence can offer an opportunity to look at the interaction of climate and population from a different perspective.

Emerging biochemical proxies, such as faecal stanols ${ }^{28}$ and bile acids, ${ }^{29}$ can be used to estimate past human population densities, and will help provide a narrative about ancient Maya responses to climate change. The principle underlying the use of these molecules is that the amount of waste produced by the local population and transported to the lake was proportional to the number of people who lived in the catchment. Thus, stratigraphic changes in the quantity of a particular biomarker such as coprostanol reflects shifts in the amount of human waste transferred to the lake, which in turn was reflected of human population numbers. Archaeological approaches to inferring demographic changes rely on identifying house structures and making assumptions about the number of inhabitants per household and whether such structures were occupied continuously and simultaneously. Estimates also rely on information about the size of the dwelling unit i.e., residential floor area per person, ${ }^{30}$ and sometimes include assumptions about hidden or "invisible" structures. ${ }^{31}$ The number of people per household has often been estimated using modern Maya ethnographic studies, however, if these numbers prove to be different for past Maya communities then we must remain sensitive to the possible error to estimates of ancient population density. ${ }^{32}$ Moreover, LIDAR (light detection and ranging) has proven to be another useful method of identifying potential housing structures and has revealed large areas of structures hidden in the Maya forest, but such images do not provide a diachronic picture of

25. Barbara W. Leyden, "Man and Climate in the Maya Lowlands," Quaternary Research 28, no. 3 (November 1987): 407-414, https://doi.org/10.1016/0033-5894(87)90007-X; Mueller et al., "Recovery of the Forest Ecosystem," 523526.

26. David A. Hodell, Mark Brenner, and Jason H. Curtis, "Terminal Classic Drought in the Northern Maya Lowlands Inferred from Multiple Sediment Cores in Lake Chichancanab (Mexico)," Quaternary Science Reviews 24, no. 12-13 (July 2005): 1413-1427, https://doi.org/10.1016/j.quascirev.2004.10.013.

27. Nicholas P. Evans et al., "Quantification of Drought during the Collapse of the Classic Maya Civilization," Science 361, no. 6401 (August 2018): 498-501, https://doi.org/10.1126/science.aas9871.

28. A. J. White et al., "An Evaluation of Fecal Stanols as Indicators of Population Change at Cahokia, Illinois," Journal of Archaeological Science 93 (May 2018): 129-134, https://doi.org/https://doi.org/10.1016/j.jas.2018.03.009.

29. Renata Zocatelli et al., "Fecal Biomarker Imprints as Indicators of Past Human Land Uses: Source Distinction and Preservation Potential in Archaeological and Natural Archives," Journal of Archaeological Science 81 (May 2017): 79 89, https://doi.org/10.1016/j.jas.2017.03.010.

30. Shannon Birch-Chapman et al., "Estimating Population Size, Density and Dynamics of Pre-Pottery Neolithic Villages in the Central and Southern Levant: An Analysis of Beidha, Southern Jordan," Levant 49, no. 1 (March 2017): 1-23, https://doi.org/10.1080/00758914.2017.1287813.

31. Aline Magnoni, "Population Estimates at the Ancient Maya City of Chunchucmil, Yucatán, Mexico," in Digital Discovery: Exploring New Frontiers in Human Heritage. CAA2006. Computer Applications and Quantitative Methods in Archaeology. Proceedings of the 34th Conference, ed. Clark, J.T. and E.M. Hagemeister (Budapest: Archaeolingua, 2006), 159-166.

32. William A. Haviland, "Family Size , Prehistoric Population Estimates, and the Ancient Maya Society," American Antiquity 37, no. 1 (Jan 1972): 135-139, http://www.jstor.org/stable/278895. 
changing occupation through time. ${ }^{33}$ Lake core records offer the potential to test or complement inferences based on traditional archaeological methods.

\section{Mechanisms of Societal Restructuring or "Collapse"}

Throughout their history, the Lowland Maya responded and adapted to various ecological and environmental challenges, including severe s between 800 and $1000 \mathrm{CE}$. Some of the ways in which they responded to these challenges are discussed in the following section.

\section{Drought}

Societal response to drought revolves around the reduced availability of water. Water is necessary for drinking, bathing, and agriculture. In regions with pronounced wet and dry seasons, even intra-annual water scarcity can pose a problem. Lisa Lucero, Joel Gunn, and Vernon Scarborough note that excess water can be equally destructive, for instance, excess water can destroy infrastructure and flood agricultural fields which will inevitably cause famine and compromise water quality. ${ }^{34}$ There is some archaeological evidence indicating this very problem in the Lowland Maya region. At Ucanal, a site in northern Guatemala, there is evidence that the Maya implemented strategies to reduce the amount of water at the site by constructing causeways and canals. ${ }^{35}$ Intra-annual variability in water availability, caused by intense seasonal rainfall, posed a serious challenge for the ancient Maya. Nevertheless, the fact that lowland cities and towns flourished for many centuries shows that the ancient Maya developed ingenious strategies to cope with the challenge of seasonal water scarcity.

They were able to access surface water from lakes and cenotes, in addition to going into caves to retrieve water from the aquifer or from haltunes they had installed to collect cave drip water. Moreover, they built chultunes (underground cisterns), dams and reservoirs to store water for future use. Nonetheless, problems still afflicted the Maya when such water management strategies ceased to function in the face of extreme climate conditions. In the Maya Lowlands, these problems arose when severe droughts occurred and the systems designed to deal with seasonal water shortages were insufficient to cope with multi-year rainfall deficits. The response of the ancient Maya to drought has been described as "on-going management of disasters"; a society on a knife's edge and only one disaster away from demise ("ecological disaster management"). ${ }^{36}$

Water management strategies were especially important in the southern Maya Lowlands where the water table was too deep to be accessed by digging wells. However, Aguadas which are natural water-filled depressions, are common in the area. Thus, reservoirs were constructed at some sites to collect runoff water during the wet season and canals were dug to direct runoff water into storage areas. As cities grew, particularly in the Late Classic period, these systems evolved and were expanded in size and complexity. Early failures, such as the siltation of reservoirs, helped inform later strategies, which were better equipped to adapt to the increasing population and greater water scarcity. Seasonality of rainfall and the need to provide water for a large population with a variety of needs requires an integrated management system. One instance of such a system is at the site of Pich, in Campeche Mexico, where a reservoir with water lilies is shaded by pich trees (Enterolobium cyclocarpum) to reduce evaporation,

33. Marcello A. Canuto et al., "Ancient Lowland Maya Complexity as Revealed by Airborne Laser Scanning of Northern Guatemala,” Science 361, no. 6409 (September 2018): 1-19, https://doi.org/10.1126/science.aau0137.

34. Lucero, Gunn, and Scarborough, "Climate Change." 479-494.

35. Christina T. Halperin, Jean Baptiste Le Moine, and Enrique Pérez Zambrano, "Infrastructures of Moving Water at the Maya Site of Ucanal, Petén, Guatemala," Journal of Anthropological Archaeology 56 (December 2019): 101102, https://doi.org/10.1016/j.jaa.2019.101102.

36. Douglas et al., "Impacts of Climate Change," 613-645. 
and receives water redirected from a stream through a canal to purify it, with people dedicated to cleaning and maintaining the reservoir system. ${ }^{37}$

Between 750 and 950 CE (Table 1), monumental construction at many large Maya ceremonial centres ceased and the cities were abandoned. This suggests that water management strategies, which were constantly being modified and pushed to their limit, could no longer sustain the population. Quantitative estimates of rainfall reduction suggest that annual precipitation decreased between 41 and $54 \%$ and up to $70 \%$ during drought periods. ${ }^{38}$ The precarious nature of management strategies supports the ecological disaster management model. Management strategies not unlike those used by the ancient Maya are still used today, and those recommended by the Intergovernmental Panel on Climate Change include water conservation, construction of reservoirs and irrigation infrastructure, in addition fallowing and the use of cover crops were essential to respond to projected future increases in temperature and rainfall reduction. ${ }^{39}$

Drought, and the consequent decline in water availability, was not only reflected in archaeological evidence for warfare and the abandonment of Maya cities, but was also apparent in the art of the time. There are multiple examples demonstrating the importance of water and how it manifested in Maya art and architecture. At Tikal, it is seen in the transposition of the Mexican rain god Tlaloc into the Maya rain god Chac, who was also a symbol of royal power and authority, perhaps reinforcing royal authority in a time when possibly the king was called into question. ${ }^{40}$ Offerings of freshwater snail shells, often along with crocodiles and turtles were also found at Tikal; offerings which seemed to coincide with a decrease in the remains of such aquatic fauna in local middens. ${ }^{41}$ Written sources suggest that scattering of bead-like objects and rain-beckoning rituals were common during periods of drought, and may have been used as a coping strategy. Ethnological work has shown that effigies of Christian saints and undoubtedly those of rain gods, or Paddler Gods, ${ }^{42}$ are taken from the church, bathed, and left in the sun. One Paddler God is the Old Jaguar Paddler and the other is the Stingray Paddler. The bead-like objects that are depicted as being scattered may represent kernels of maize, blood, or water. ${ }^{43}$

\section{Deforestation and Soil Nutrient Loss}

Humans may have exacerbated the effects of climate change through deforestation. The feedback effect of forest land clearance reduces precipitation and increases evapotranspiration, which would lead to a decrease in water availability. When forest trees are removed, rainfall is not able to infiltrate the vegetation, instead it hits directly the bare ground and contributes to soil erosion and floo-

37. Lucero, Gunn, and Scarborough, "Climate Change," 479-494.

38. Evans et al., "Quantification of Drought," 498-501.

39. Graciela O. Magrin et al., "Central and South America," in Climate Change 2014: Impacts, Adaptation and Vulnerability. Part B: Regional Aspects. Contribution of Working Group II to the Fifth Assessment Report of the Intergovernmental Panel on Climate Change, ed. V.R. Barros et al. (Cambridge: Cambridge University Press, 2014), 1499-1566, https://doi.org/10.5860/choice.45-5008.

40. Clemency C. Coggins, "A New Order and the Role of the Calendar: Some Characteristics of the Middle Classical Period at Tikal," in Maya Archaeology and Ethnohistory, ed. N Hammond and G. R. Willey (Austin, TX: University of Texas Press, 1979), 38-50; Bruce H. Dahlin, "Climate and Prehistory on the Yucatan Peninsula," Climatic Change 5, no. 3 (September 1983): 245-263, https://doi.org/10.1007/BF02423521.

41. Hattula Moholy-Nagy, "Utilization of Pomocea Snails at Tikal, Guatemala," American Antiquity 43, no. 1 (January 1978): 65-73; Dahlin, "Climate and Prehistory," 245-263.

42. "Paddler Gods" are paired deities seen often ferrying gods in a dugout canoe.

43. Eva Jobbová, Christophe Helmke, and Andrew Bevan, "Ritual Responses to Drought: An Examination of Ritual Expressions in Classic Maya Written Sources," Human Ecology 46, no. 5 (October 2018): 759-781, https://doi.org/10.1007/s10745-018-0019-6. 
ding. ${ }^{44}$ Regional climate simulations show that removal of trees causes warmer, drier conditions, and illustrate the negative impacts of deforestation. ${ }^{45}$ Sediment cores from Lake Salpeten, northern Guatemala, showed there was early and rapid soil loss as a consequence of land clearance. Loss of soil from deforestation, combined with reduction of soil nutrients as a consequence of intensive farming, may have contributed to a situation in which soil fertility became too poor to grow sufficient food. The large demand for fuel (i.e., firewood) to produce lime and stucco for construction in the Late Classic period, also put pressure on forests. ${ }^{46}$ During the Terminal Classic period, the south is thought to have "collapsed" as much as two centuries before the north. However, it is difficult to explain why Maya urban centres in the drier north outlasted those in the wetter southern Maya Lowlands. Differences in the extent of deforestation around population centres have been proposed as an explanation for difference in timing of collapse between sites in the north and south, and among sites within the south. Although deforestation affected the whole region, more intense deforestation in one place versus another might explain the temporal differences in collapse. ${ }^{47}$ Evidence from lake sediment cores suggests deforestation was intense and widespread in the south well before the Late Classic period, which could explain the failure of southern population centres. Intense deforestation could explain the increase of drying or soil loss in the hilly terrain of the south, and as a consequence the failure of agriculture. Other effects of deforestation might have included loss of habitat and food sources for wildlife such as deer, which may have caused food shortages and nutritional deficiencies for the Maya. This may, in turn, have had repercussions that contributed to the restructuring of Lowland Maya society. During the Classical period, at Lake Salpeten, the soil erosion rate declined, this despite very high population density in the basin and evidence of widespread deforestation. This could reflect the decreasing erodibility of soil through time (i.e., erodible soil had already been largely transported to the lake) but may also suggest that soil loss was recognised as a problem and strategies had been put in place to counter this loss and conserve soil. ${ }^{48}$

Slash-and-burn agriculture is a strategy whereby forest is cut down, dried and then burned this occurs before planting and prior to the onset of the wet season. Scholars believed this agricultural method to have been the dominant agricultural practice of the ancient Maya. The method is most effective where population density is low, as agricultural plots can only be exploited for a few years at most, and then must be fallowed for a considerable time to enable regrowth of vegetation. However, Ursula Cowgill, one of the first researchers to document the "Maya collapse," noted that the time required for land to "rest" is relatively short in Peten, Guatemala. This led her to contrast the conditions observed in Peten with the longer fallow period required in the northern Yucatan Peninsula. ${ }^{49}$ Alternatively, some scholars suggest that the ancient Maya were not responsible for widespread deforestation and propose an alternative model of human-environment interaction based on contemporary ethnoecology. Ababel Ford and Ronald Nigh believe that the pollen and sedimentological records are evidence for climate-driven changes in forest composition, rather than the result of agricultural impacts, and that the ancient Maya simply altered the natural forests to make the most of,

44. Justine M. Shaw, "Climate Change and Deforestation: Implications for the Maya Collapse," Ancient Mesoamerica 14, no. 1 (January 2003): 157-167, https://doi.org/10.1017/S0956536103132063.

45. Robert J. Oglesby et al., "Collapse of the Maya: Could Deforestation Have Contributed?," Journal of Geophysical Research Atmospheres 115, no. 12 (June 2010): 1-10, https://doi.org/10.1029/2009JD011942.

46. B. L. Turner and Jeremy A. Sabloff, "Classic Period Collapse of the Central Maya Lowlands: Insights about HumanEnvironment Relationships for Sustainability," Proceedings of the National Academy of Sciences of the United States of America 109, no. 35 (August 2012): 13908-13914, https://doi.org/10.1073/pnas.1210106109.

47. Shaw, "Climate Change and Deforestation," 157-167.

48. Flavio S. Anselmetti et al., "Quantification of Soil Erosion Rates Related to Ancient Maya Deforestation," Geology 35, no. 10 (October 2007): 915-918, https://doi.org/10.1130/G23834A.1.

49. Ursula M. Cowgill, "An Agricultural Study of the Southern Maya Lowlands," American Anthropologist 64, no. 2 (1962): 273-286, https://doi.org/10.1525/aa.1962.64.2.02a00030. 
and to adapt to, changing climate. They did this by creating what the authors describe as the "Maya Forest Garden," which incorporated the milpa cycle, and involved a land use pattern that shifted from closed-canopy forest, to annual crops collected from open fields, to a managed orchard garden, and then back to forest. This system allowed the Maya to sustain soil fertility and contributed to greater plant diversity. The authors suggest that this low-risk, stable management system enabled increase food production to meet the needs of a growing population. ${ }^{50}$ Because the landscape was a mix of human households, forest garden, and wild forest that co-existence with animal habitats such as jaguar, tapir and deer was possible. A mixture of agricultural strategies would have enabled successful food production necessary to feed large numbers of people during the Classic.

\section{Maya Agricultural Systems Response}

In the Early Classic Period, terracing on some upland slopes was implemented to reduce erosion and soil nutrient loss. Timothy Beach et al. hypothesised that limestone on the Vaca Plateau in Belize inspired the Maya to build terraces, as the local bedrock had naturally weathered into linear, step-like terraces. ${ }^{51} \mathrm{~A}$ variety of innovative agricultural methods were employed by the ancient Maya to deal with decreasing water supplies, degradation of soil quality, and rising demand of food production due to population growth. For instance, lime found in a fossil field at the site of Nakbe, in Peten Guatemala, may have been used to reduce soil acidity in the bajos (seasonal wetlands). There is also evidence from Nakbe that mud was imported to construct a terrace. Such strategies were implemented at many sites to support increasingly larger populations. Richard Hansen et al. argued that large bajos may have become marshlands that possessed many resources, including wildlife, organic soils, and fibres; they argued that muck from these marshlands could have been used to enrich agricultural fields. ${ }^{52}$ However, they also conceded that "the precise source of the mud is probably still conjecture" and noted that "the Palma causeway at Nakbe ends in the southern bajo, suggesting that the causeway may have facilitatedbajo muck, among other resources, into the civic centre." 53

The question that then arises is whether the bajos could become marshlands in a matter of months during the wet season? Preliminary data from a lake in the southwest Maya Lowlands suggest a large decrease in faecal input to the lake at the end of the Preclassic period, which could reflect population change, but could also represent changes in agriculture strategies. ${ }^{54}$ Construction of the causeway at Nakbe might have been intended to deal with two challenges: 1) managing human waste in the urban centre by ferrying it to the bajos, and 2) turning such waste into a resource, i.e. fertiliser for the agricultural fields. Fertiliser made from human waste, also known as night soil, was used extensively in the past, and is still used today in China and India. ${ }^{55}$ In East Asia, night soil was so valuable that it was referred to as "golden juice."

50. Anabel Ford and Ronald Nigh, "Origins of the Maya Forest Garden: Maya Resource Management," Journal of Ethnobiology 29, no. 2 (December 2009): 213-236, https://doi.org/10.2993/0278-0771-29.2.213.

51. Timothy Beach et al., "Upland Agriculture in the Maya Lowlands: Ancient Maya Soil Conservation in Northwestern Belize," Geographical Review 92, no. 3 (July 2002): 372, https://doi.org/10.2307/4140916.

52. Richard D. Hansen et al., "Climatic and Environmental Variability in the Rise of Maya Civilization: A Preliminary Perspective from Northern Peten," Ancient Mesoamerica 13, no. 2 (July 2002): 273-295, https://doi.org/10. 1017/S0956536102132093.

53. Hansen et al., "Climatic and Environmental," 283-295.

54. Benjamin Keenan et al., "Molecular Evidence for Human Population Change Associated with Climate Events in the Maya Lowlands," Quaternary Science Reviews Forthcoming 2021.

55. Pramod R. Chaudhari et al., "Integrated Water-Less Management of Night Soil for Depollution of Water Resources and Water Conservation," Journal of Engineering Research and Applications 6, no. 5 (May 2016): 47-53.

56. Nicholas C. Kawa et al., "Night Soil: Origins, Discontinuities, and Opportunities for Bridging the Metabolic Rift," Ethnobiology Letters 10, no. 1 (2019): 40-49, https://doi.org/10.14237/ebl.10.1.2019.1351. 
guage) by the Aztecs was well documented in central Mexico to achieve tlalauiyac, which is described as follows:

[...] the land which is good, which produces, which is mellow. I fertilize it. I add humus to it. I make it mellow. I make it good. ${ }^{57}$

Much is known about soil-plant relationships among the Aztecs, who are said to have made associations between soil fertility, midden heaps and residential sites. ${ }^{58}$ In addition to the ash, from slash-and-burn practices, and in the absence of large domesticated animals, the main source of fertiliser was night soil. ${ }^{59}$ This waste material was incorporated into raised fields in swamps and shallow lakes, which would combine with vegetation and lake sediment to make floating island gardens (chinampas) that were used to grow a variety of food, including maize. ${ }^{60}$ These were not dissimilar to the wetland fields, and were used extensively by the Aztecs. ${ }^{61}$

Use of human waste as a biofertilizer provides a source of nutrients for soils, helps conserve water, and improves public health by preventing contamination of water resources. ${ }^{62}$ It is likely that Maya farmers also recognised the relationship between human waste and the benefits to soil and plant health, which has led scholars to suggest that they too probably used night soil. The Aztecs occupied central Mexico in the Postclassic period and thus, might have obtained this knowledge from the Maya. Several studies allude to the use of night soil as fertiliser in the Maya Lowlands. ${ }^{63}$ High concentrations of phosphorus in terrace soils have been interpreted as reflecting the use of fertiliser application. ${ }^{64}$ Higher-than-average phosphorus concentrations were interpreted as evidence of tree fertilisation with night soil at a house garden at Las Pozas, Guatemala. ${ }^{65}$ Use of night soil in multiple agricultural contexts (large terraces and local gardens) suggests it was a widely used agrarian method that was probably applied across a broad geographic range.

The bajo-marshland system described above could have served as a receptacle for human waste, which formed part of the muck derived from the marshlands. Furthermore, the bajos may have even replaced upland fields for agricultural production during protracted dry periods. There is a decreasing trend in consumption of freshwater snails at the end of the Preclassic period. ${ }^{66}$ This could have been a consequence of habitat desiccation but might also reflect the fact that lakes were polluted, and water quality was degraded to the extent that snails could no longer survive under such conditions or were themselves contaminated. In fact, the total concentration of coliform bacteria and Escherichia coli - in particular - increase in the aguadas (natural or human made ponds) when water levels drop during dry periods ${ }^{67}$ Recognition that water sources were contaminated may have led to efforts to reduce the amo-

57. Gene C. Wilken, Good Farmers: Traditional Agricultural Resource Management in Mexico and Central America (Berkley: University of California Press, 1990), 24.

58. For further discussion see Benno Warkentin, Footprints in the Soil: People and Ideas in Soil History (Burlington: Elsevier Science, 2006).

59. For further discussion see Dirk Van Tuerenhout and John Weeks, The Aztecs: New Perspectives (Santa Barbara, California: ABC-CLIO, 2005); Susan T. Evans, "The Productivity of Maguey Terrace Agriculture in Central Mexico during the Aztec Period," Latin American Antiquity 1, no. 2 (June 1990): 117-132, https://doi.org/10.2307/971983.

60. Warkentin, Footprints in the Soil.

61. Evans, "The Productivity of Maguey Terrace," 117-132.

62. Chaudhari et al., "Integrated Water-Less Management," 47-53.

63. Ryan V. Sweetwood et al., "The Maya Footprint: Soil Resources of Chunchucmil, Yucatán, Mexico," Soil Science Society of America Journal 73, no. 4 (July 2009): 1209-1220, https://doi.org/10.2136/sssaj2008.0262.

64. Beach et al., "Upland Agriculture in the Maya Lowlands," 372-397.

65. Fabián G. Fernández et al., "An Ethnoarchaeological Study of Chemical Residues in the Floors and Soils of Q'eqchi' Maya Houses at Las Pozas, Guatemala," Geoarchaeology 17, no. 6 (August 2002): 487-519, https://doi.org/ 10.1002/gea.10026.

66. Dahlin, "Climate and Prehistory," 245-263.

67. Hansen et al., "Climatic and Environmental," 283-295. 
unt of human waste to lakes through the construction of terraces and use of waste as fertiliser. Terraces would also have reduced sediment input to lakes from soil erosion.

In the Late Classic period, the ancient Maya employed a wide range of agricultural and land management strategies to support their growing populations and flourishing society. Widespread field and terrace walls are present at Chunchucmil in northwest Yucatán, where we find an ancient Maya village with poor crop and soil potential. ${ }^{68}$ Rural hamlets with orchards and fields, that sometimes incorporate wetlands or walled fields, are ubiquitous. ${ }^{69}$ The orchard system is evocative of the Maya Forest Garden system, which was described above, and implies a holistic approach to management of resources across the landscape. Expansion of agricultural strategies developed early in Maya history occurred as the population grew and the ability to secure food and water changed. The combination of methods used at Chunchucmil would not only have satisfied local food requirements but would also have served to limit further degradation of nutrients found in soil stores and protect valuable water resources.

That said, there were other challenges associated with Maya food production, which included crop failures, as well as problems associated to storage and distribution of food produced. In addition, cultivated maize, a staple crop of the Lowland Maya, has less resistance to pests than teosinte, the wild ancestor of corn. Loss of the protective casing around teosinte kernels in domesticated maize makes it consumable by humans, but also more vulnerable to pathogens and herbivores. ${ }^{70}$ James Brewbaker hypothesised that it was the vulnerability of maize to disease that contributed to the Maya decline. ${ }^{71}$ Maize mosaic virus is thought to have been an important factor in the collapse of Maya civilization, by causing widespread crop failure. The author compares the maize crop failure to the "late blight" that caused the Irish potato famine in 1845. In addition to viruses, in the humid tropics, maize is subject to foliar diseases including blights, mildews, and stalk, ear and kernel rots. ${ }^{72}$

Moreover water availability is a limiting factor in maize production. ${ }^{73}$ Water scarcity during droughts at the end of the Classic Period may have been so severe that maize yields declined or failed entirely. Although drought may have affected populations across the Maya Lowlands, local impacts probably differed and individuals may have been affected depending on their position in the social hierarchy. The political elite had access to a greater diversity of foods and ate more meat, whereas the lower classes relied more heavily on maize to meet their dietary requirements. ${ }^{74}$ The importance of maize means that corn crop failures would have had unequal effects on the population, among the lower classes this would have meant a loss of their principal food source, whereas among members of the upper classes this loss would have been compensated with other nutrient-rich foods. Unequal distribution and access to food could have triggered discontent with rulers, social uprisings, and substantial illness and death among workers who maintained the complex agricultural systems. The situation could also have caused mass migrations to areas that were better provisioned, such as the coast. Other implications of reduced food access include greater susceptibility to disease, which will be discussed later in the article.

68. Timothy Beach, "Soil Constraints on Northwest Yucatán, Mexico: Pedoarchaeology and Maya Subsistence at Chunchucmil," Geoarchaeology 13, no. 8 (December 1998): 759-791.

69. Turner and Sabloff, "Classic Period Collapse," 13908-13914.

70. Elvira S. de Lange et al., "Insect and Pathogen Attack and Resistance in Maize and Its Wild Ancestors, the Teosintes," New Phytologist 204, no. 2 (2014): 329-341, https://doi.org/10.1111/nph.13005.

71. James L. Brewbaker, "Diseases of Maize in the Wet Lowland Tropics and the Collapse of the Classic Maya Civilization," Economic Botany 33, no. 2 (1979): 101-118, http://www.jstor.org/stable/4254035.

72. Brewbaker, "Diseases of Maize," 101-118.

73. Youhong Song et al., "Analysis and Modelling of the Effects of Water Stress on Maize Growth and Yield in Dryland Conditions," Plant Production Science 13, no. 2 (2010): 199-208, https://doi.org/10.1626/pps.13.199.

74. Lori E. Wright, "Biological Perspectives on the Collapse of the Pasion Maya," Ancient Mesoamerica 8, no. 2 (Fall 1997): 267-273, https://doi.org/10.1017/S0956536100001723. 
Maya agriculture, which had been successful in providing food for large numbers of people for centuries, was also able to endure crop failures brough upon by droughts and plant diseases, highlighting not only the agricultural system's capacity to adapt but also its fragility under changing climate conditions. Later, attempts by the Spanish to introduce other grains in Yucatan were unsuccessful. Production of maize as the staple crop still continues in the region today and seems to be the best agricultural option for that environment. ${ }^{75}$ Soil degradation and rainfall variability during the early periods of Maya occupation were recognised and addressed in a variety of ways. The success of these strategies over the long term speak to the ability of the Maya to identify and solve problems that arose, in addition to being able to sustain growing populations in areas with limited resources. Despite this resilience and endurance on the part of the Maya we are still left with the question of why and how these systems failed?

\section{Responses Across the Maya Lowlands}

The cities that collapsed or experienced pronounced population declines were located in the Elevated Interior Region. This is an area where the water table is deep below the land surface and people relied on surface waters (lakes and rivers) and water collection techniques (i.e. aguadas, chultunes, dams, reservoirs, etc.). One possible explanation for the collapse is that as the climate became drier, water was less abundant, and this inevitably led to agricultural failure, famine and eventual breakdown of the society. Julia Hoggarth et al. discusses the role of exogenous "shocks" on demography ${ }^{76}$ with reference to Wood's 1998 model, which posits that as the population in an area grows and resource availability, or the standard of living, declines either population numbers will shrink until the availability of resources matches the number of people, or adaptations will be implemented to support the growing number of people. ${ }^{77}$ The finely balanced system, referred to as "ecological disaster management," would have also been very sensitive to external influences such as climate variability or political change in neighbouring polities.

Lack of water could have had other implications, for instance the drying of moats might have facilitated incursions southward. ${ }^{78}$ Dahlin referred to the population loss in the northern two-thirds of the Yucatan Peninsula during the Terminal Preclassic and Early Classic periods, as the result of invasions from the north. ${ }^{79}$ The presence of defensive earthworks also further supports this argument. These fortified sites are thought to have failed, either because they were overwhelmed by invaders or were victims of climate change. Sites in the Maya Lowlands did not constitute a single unified political entity, but rather a number of discrete, but interacting polities, so warfare resulting from competition for dwindling resources is a plausible scenario. Later, Postclassic period collapses in northern areas with aquifer access, such as Chichén Itzá, may be attributed to migrant influxes of people from failed, postdrought city-states. It is easy to imagine a scenario where dwindling resources and political failure to deal with the situation led to a discontent working class that realised their collective power and overthrew their rulers, - divine kings known as k'ujul ajaw. Another possible scenario is that the resources became scarce due to increased competition between neighbouring city-states vying for the

75. Cowgill, "An Agricultural Study," 273-286.

76. Julie A. Hoggarth et al., "Drought and Its Demographic Effects in the Maya Lowlands," Current Anthropology 58, no. 1 (February 2017): 82-113, https://doi.org/10.1086/690046.

77. James W. Wood, "A Theory of Preindustrial Population Dynamics: Demography, Economy, and Well-Being in Malthusian Systems,” Current Anthropology 39, no. 1 (February 1998): 99-135, https://doi.org/10.1086/204700.

78. Sheryl Luzzadder-Beach et al., "Sky-Earth, Lake-Sea: Climate and Water in Maya History and Landscape," Antiquity 90, no. 350 (April 2016): 426-442, https://doi.org/10.15184/aqy.2016.38.

79. Dahlin, "Climate and Prehistory," 245-263. 
same resources. It is also conceivable that an influx of refugees came to an area which was already agriculturally fragile and caused a depletion of resources, thus creating an irreparable imbalance.

\section{Climate and Infectious Diseases}

The movement of people coupled with lack of food and water resources may have led to conditions where disease could spread more easily. Given that the Maya were able to successfully adapt to changing climate and growing population density over many centuries, the system could have been thrown out of balance with the arrival of new diseases. Smallpox was brought over with the arrival of the Spanish; European exploration introduced several deadly diseases that decimated indigenous Americans farther north. ${ }^{80}$ There is the possibility that a disease emerged among the ancient Maya before the Spanish arrived, which caused massive population loss at the end of the Classic period. However, if this was the case agricultural innovation would not have been much help, unless there were pre-existing dietary deficiencies that reduced resistance to disease or the ability to fight it. Thus, it is important to keep in mind that the spread of disease could have occurred under several different circumstances within Lowland Maya society.

The lack of abundant nutritious food, caused by increased demand or declining agricultural yields (as a result of soil degradation or climate change), may have arguably made people less resistant to disease and more vulnerable to infections. A diet predominantly consistent of maize does not provide adequate nutrition, even if supplemented with tropical fruits, beans and squash. ${ }^{81}$ As noted above, the elite members of society ate less corn, more meat and had greater access to varied foods. ${ }^{82}$ The collapse of agricultural systems, along with the loss of freshwater fish and shellfish which provided a rich source of protein, could have created a need for alternative meat sources. In addition, dependency on maize is thought to have been responsible for the low iron in Maya diets. ${ }^{83}$ Limited consumption of foods rich in iron can lead to an important iron deficiency and result in anaemia. The level of iron in one's system can also be affected by disease (inflammation or infection) and parasite infections, which can reduce absorption of iron in the intestines and cause intestinal bleeding. This nutritional stress would have contributed to the weakening of the overall immune system. Studies of collagen and bone in Maya skeletons from sites in the Pasión region revealed no evidence of infectious disease, anaemia and/or dental growth disruption, thus suggesting that the collapse occurred as a result of socio-political upheaval. ${ }^{84}$ The lack of evidence for anaemia is potentially explained by the fact that meat consumption continued unabated. Indeed, stable nitrogen isotope data from the Pasión region suggest that animal protein remained available into the Terminal Classic period. ${ }^{85}$

Given that the human population increased and wild animal habitat decreased, as a consequence of deforestation (although perhaps there were refugia in the Maya Forest Garden model), alternative sources of meat may have been exploited. Moreover, infections can result from consuming contaminated meat and from proximity to animals (i.e. zoonotic diseases), as the barrier between forest

80. Christina Warinner et al., "Disease, Demography, and Diet in Early Colonial New Spain: Investigation of a Sixteenth-Century Mixtec Cemetery at Teposcolula Yucundaa," Latin American Antiquity 23, no. 4 (December 2012): 467-489, https://doi.org/10.7183/1045-6635.23.4.467.

81. Robert S. Santley, Thomas W Killion, and Mark T Lycett, "On the Maya Collapse," Journal of Anthropological Research 42, no. 2 (1Summer 986): 123-159, http://www.jstor.org/stable/3630485.

82 . Lori E. Wright and Christine D. White, "Human Biology in the Classic Maya Collapse: Evidence from Paleopathology and Paleodiet," Journal of World Prehistory 10, no. 2 (June 1996): 147-198.

83. Lori E. Wright and Francisco Chew, "Porotic Hyperostosis and Paleoepidemiology: A Forensic Perspective on Anemia among the Ancient Maya," American Anthropologist 100, no. 4 (December 1998): 924-939, https://doi.org/10.1525/aa.1998.100.4.924.

84. Wright, "Biological Perspectives," 267-273.

85. Wright and White, "Human Biology," 147-198. 
and human habitat is reduced as a result of population increase and deforestation. Furthermore, transmission of simian foamy virus can occur through bites or scratches. ${ }^{86}$ Human immunodeficiency virus type 2 is thought to have originated from simian immunodeficiency viruses, strains of which can be found in bush meat in Sierra Leone, a virus prevalent in wild monkeys ${ }^{87}$ In addition to transmission of disease from non-human primates, there is evidence of transmission of viruses from other animal species. In 2003-2004 it was shown that several people contracted severe acute respiratory syndrome (SARS) from consuming palm civets that tested positive for SARS-associated coronavirus. ${ }^{88}$ Bats have also been identified as reservoirs of coronaviruses associated with the outbreak of SARS. ${ }^{89}$ Bats are considered to be the likely source for SARS-CoV-2, i.e. COVID-19. ${ }^{90}$ Bush meat has often been the source of viral infections in recent history. A plausible explanation for this recent manifestation of viral infection can be due to environmental degradation, which facilitates the crossover of viruses to humans from animals living in the forest. Lori Wright and Christine White have suggested that the decrease in maize consumption in ancient Maya communities, caused by declining yields, could have been supplemented with wild foods. ${ }^{91}$ If this wild food included bush meat, the issue of iron deficiency and anaemia would have been solved, but may have increased the risk of zoonotic disease transmission and outbreak.

Some of the agricultural strategies described above, such as the use of night soil for fertiliser to help meet the dietary demands of an increasing population, may have contaminated food plants and led to typhoid epidemics. ${ }^{92}$ Contamination of water supplies with faeces (particularly during dry periods) may have also contributed to the spread of parasites and infectious diseases. Rodolfo Acuna-Soto et al. compare the Late Classic Maya period demise with the depopulation of central Mexico in the sixteenth century, when $80-90 \%$ of the indigenous population was lost and hypothesise that the collapse was the result of haemorrhagic fevers - a phenomena that also occurs during sustained drought. ${ }^{93}$ Another factor to take into consideration is the migration of individuals from different places as a consequence of climate change. If high concentrations of migration occurred in areas that had sufficient water resources this could have spread disease, under conditions of increased population density, malnutrition, and greater exposure to pathogens. Contaminated water supplies, some polluted by human waste, may have spread water-borne illness through direct consumption of water or ingestion of aquatic fauna. In addition, drier climate could have also pushed people into concentrated areas and created conditions ripe for the spread of disease. ${ }^{94}$ Alicia Wilbur and Jane Buikstra theorized that large Late Classic pop-

86. A. Mouinga-Ondeme et al., "Cross-Species Transmission of Simian Foamy Virus to Humans in Rural Gabon, Central Africa," Journal of Virology 86, no. 2 (January 2012): 1255-1260, https://doi.org/10.1128/jvi.06016-11; Lisa Jones-Engel et al., "Primate-to-Human Retroviral Transmission in Asia," Emerging Infectious Diseases 11, no. 7 (July 2005): 1028-1035, https://doi.org/10.3201/eid1107.040957.

87. C. Apetrei et al., "Detection and Partial Characterization of Simian Immunodeficiency Virus SIVsm Strains from Bush Meat Samples from Rural Sierra Leone," Journal of Virology 79, no. 4 (February 2005): 2631-2636, https://doi.org/10.1128/jvi.79.4.2631-2636.2005.

88. Ming Wang et al., "SARS-CoV Infection in a Restaurant from Palm Civet," Emerging Infectious Diseases 11, no. 12 (December 2005): 1860-1865, https://doi.org/10.3201/eid1112.041293.

89. Wendong Li et al., "Bats Are Natural Reservoirs of SARS-like Coronaviruses," Science, New Series 310, no. 5748 (October 2005): 676-679, http://www.jstor.org/stable/3842715.

90. Domenico Benvenuto et al., "The 2019-New Coronavirus Epidemic: Evidence for Virus Evolution," Journal of Medical Virology 92, no. 4 (January 2020): 455-459, https://doi.org/10.1002/jmv.25688.

91. Wright and White, "Human Biology," 147-198.

92. T. A. Cockburn, "Infectious Diseases in Ancient Populations," Current Anthropology 12, no. 1 (1971): 45-62, https://doi.org/10.1086/201168.

93. Rodolfo Acuna-Soto et al., "Drought, Epidemic Disease, and the Fall of Classic Period Cultures in Mesoamerica (AD 750-950). Hemorrhagic Fevers as a Cause of Massive Population Loss," Medical Hypotheses 65, no. 2 (2005): 405-409, https://doi.org/10.1016/j.mehy.2005.02.025.

94. Alicia Kay Wilbur and Jane Ellen Buikstra, "Patterns of Tuberculosis in the Americas - How Can Modern Biomedicine Inform the Ancient Past?," Memorias Do Instituto Oswaldo Cruz 101, no. 2 (December 2006): 59-66, https://doi.org/10.1590/S0074-02762006001000011. 
ulations, coupled with population movement along trade routes may have been the cause of transmission of a virulent strain of tuberculosis. ${ }^{95}$

Although the detailed process of societal collapse is poorly understood it is possible that widespread disease combined with malnutrition left fewer people available to maintain the agricultural systems. ${ }^{96}$ Collapse may have occurred in a stepwise fashion with weaker, susceptible people dying first, and remaining individuals either dying from starvation, or forced to migrate. Given the lack of available water it might have been sensible to leave the area altogether.

\section{Restructuring and Abandonment of Maya Cities}

The story of the Lowland Maya informs us about an ancient society that dealt with two major environmental challenges: 1) soil erosion and loss of soil nutrients that resulted from widespread deforestation to support agricultural needs, and 2) fluctuating water supply accessibility as a consequence of climate change. Multiple factors compromise the accuracy and spatio-temporal resolution of palaeoclimate and archaeological records. Because drought and societal collapse are thought to have occurred at different times across the Maya Lowlands, with droughts in the north occurring up to two centuries later, it is clear that interactions between climate and social factors are complex. Whereas sweeping generalisations about the response of the Lowland Maya to drought have been made, the reality is that the response remains poorly understood. The theory of ecological disaster management posits that strategies were constantly being pushed to their limits, modified, and repeated until they no longer functioned. However, it is possible that natural buffers such as the presence of remnant forests enabled effective Maya response to drought at least for some time. When these natural buffers were removed completely, however, such management strategies ceased to function. Palaeoclimate data from additional sites in the Maya Lowlands will help elucidate the nuances of the ancient Maya response to droughts.

What can we learn from the ancient Lowland Maya? Climate change altered the availability of resources, mainly water, thereby playing an important role in deteriorating relations between neighbouring polities, to the extent that wars were fought over such resources and cities were eventually depopulated. Persistent mass migration to inland bodies of water and to the coasts seems to have been an outcome of climate change in the Maya Lowlands. This has interesting historical implications in that it sets the scene for Spanish colonisation centuries later and provides insights into how humans massively migrate in response to environmental change. What effects did migration have on the communities or areas which received the migrating communities? Did migration provoke further conflicts? What was the fate of people who were essentially climate refugees? Was their plight similar to that of modern-day climate refugees? Discussion of the Lowland Maya response to drought in the Terminal Classic period remains contentious. What is clear is that when we refer to societal "collapse," it does not imply that the Maya disappeared. Maya people continue to live in southern Mexico and Central America today, and some researchers have advocated that it would be more appropriate to refer to the Terminal Classic period as a period of "restructuring" where societal change occurred, rather than, a total collapse. Although it is clear that many cultural activities in the southern Maya Lowlands did cease abruptly and there was indeed widespread depopulation, however, for a number of reasons we must be cautious with the terminology we choose to describe these events. First and most importantly, referring to a period as a "collapse" can imply "cultural extinction," which does a disservice to the millions of Maya people who continue to live in the region today. Second, when we discuss the response of past civilisations to climate change, and the implications for the existential cha-

95. Wilbur and Buikstra, "Patterns of Tuberculosis," 59-66.

96. Santley, Killion, and Lycett, "On the Maya Collapse,” 123-159. 
llenge that contemporary climate change poses, it can be self-defeating to describe the problem in apocalyptic terms. It seems inevitable that the effects of modern-day anthropogenic climate change will displace more and more people. The problem stems from both the increase in greenhouse gases in the atmosphere and the fact that much of the world's population lives in areas that are or will become vulnerable. One factor that will make it difficult to migrate from uninhabitable zones in response to climate change is the way borders are controlled. If governments hope to manage the movement of people successfully, it will require investment in areas that are likely to fare well in terms of future habitability and to provide the resources necessary to sustain and protect communities. This will necessitate the reconsideration of society's core values, including the notion of citizenship, to facilitate movement of people from hazardous to safer areas. ${ }^{97}$ The Lowland Maya story is an excellent example of how humans interacted over the long term with their environment, especially in light of the emerging field of landscape sustainability. Today, we have ways to cope that the Lowland Maya did not, such as development of genetically modified, drought-resistant crops. Nevertheless, we still face many challenges in terms of developing techniques for water management.

\section{Concluding Remarks}

The cause of the decline of Classic Maya civilisation (ca. 750-900 CE) remains a subject of debate, but the demise may have been, in part, as a consequence to a series of protracted droughts. Biogeochemical records from lake sediments and cave speleothems provide the climate and environmental context for the societal changes identified through archaeology. By studying past changes in the natural world, together with socio-economic changes, we can better understand relations between climate, environment, and humans, which sadly, remain poorly understood. The story of the interaction between the Lowland Maya and changing climate provides unique insights into the response of an ancient civilisation to climate change - a useful perspective given that the effects of modern-day climate change are already being felt. Adaptation over centuries to dwindling water resources and loss of soil nutrients are testaments to Maya ingenuity, but ultimately, climate and environmental conditions may have exceeded a threshold, to which Maya society could not respond. That said, we could also view the events of the Terminal Classic period in an alternative way. Despite the widespread abandonment of cities in the Maya Lowlands, the longer-term result was a restructuring of society that enabled Maya people to persist to the present. Perhaps resourcefulness and adaptability of the ancient Lowland Maya is a lesson not only to how we should respond to climate and environmental change, but also to social and political change.

97. Ben Orlove, "Human Adaptation to Climate Change: A Review of Three Historical Cases and Some General Perspectives," Environmental Science and Policy 8, no. 6 (December 2005): 589-600, https://doi.org/10.1016/ j.envsci.2005.06.009. 


\section{Bibliography}

Acuna-Soto, Rodolfo, David W. Stahle, Matthre D. Therrell, Sergio Gomez Chavez, and Malcom K. Cleaveland. "Drought, Epidemic Disease, and the Fall of Classic Period Cultures in Mesoamerica (AD 750-950). Hemorrhagic Fevers as a Cause of Massive Population Loss." Medical Hypotheses 65, no. 2 (2005): 405-409. https://doi.org/10.1016/j.mehy.2005.02.025.

Aimers, James J. "What Maya Collapse? Terminal Classic Variation in the Maya Lowlands." Journal of Archaeological Research 15, no. 4 (September 2007): 329-377. https://doi.org/10.1007/s10 814-007-9015-x.

Anselmetti, Flavio S., et al. "Quantification of Soil Erosion Rates Related to Ancient Maya Deforestation." Geology 35, no. 10 (October 2007): 915-918. https://doi.org/10.1130/G2383 $\underline{4 A .1 .}$

Apetrei, Cristian, Michael J. Metzger, David Richardson, Binhua Ling, Paul T. Telfer, Patricia Reed, David L. Robertson, and Preston A. Marx. "Detection and Partial Characterization of Simian Immunodeficiency Virus SIVsm Strains from Bush Meat Samples from Rural Sierra Leone." Journal of Virology 79, no. 4 (February 2005): 2631-2636. https://doi.org/10.1128/jvi. 79.4.2631-2636.2005.

Beach, Timothy. "Soil Constraints on Northwest Yucatán, Mexico: Pedoarchaeology and Maya Subsistence at Chunchucmil." Geoarchaeology 13, no. 8 (December 1998): 759-791.

, Sheryl Luzzadder-Beach, Nicholas Dunning, Jon Hageman, and Jon Lohse. "Upland Agriculture in the Maya Lowlands: Ancient Maya Soil Conservation in Northwestern Belize." Geographical Review 92, no. 3 (July 2002): 372-397. https://doi.org/10.2307/4140916.

Benvenuto, Domenico, Marta Giovanetti, Alessandra Ciccozzi, Silvia Spoto, Silvia Angeletti, and Massimo Ciccozzi. "The 2019-New Coronavirus Epidemic: Evidence for Virus Evolution.” Journal of Medical Virology 92, no. 4 (January 2020): 455-459. https://doi.org/10.1002/jmv. 25688.

Birch-Chapman, Shannon, Emma Jenkins, Fiona Coward, and Mark Maltby. "Estimating Population Size, Density and Dynamics of Pre-Pottery Neolithic Villages in the Central and Southern Levant: An Analysis of Beidha, Southern Jordan.” Levant 49, no. 1 (March 2017): 1-23. https://doi.org/10.1080/00758914.2017.1287813.

Brewbaker, James L. "Diseases of Maize in the Wet Lowland Tropics and the Collapse of the Classic Maya Civilization.” Economic Botany 33, no. 2 (1979): 101-118. http://www.jstor.org/stable/ $\underline{4254035 .}$

Buckley Brendan M., Kevin J. Anchukaitis, Daniel Penny, Roland Fletcher, Edward R. Cook, Masaki Sano, Lo Canh Nam, Aroonrut Wichienkeeo, Ton That Minh, and Truong Mai Hong. "Climate as a Contributing Factor in the Demise of Angkor, Cambodia." Proceedings of the National Academy of Sciences of the United States of America 107, no. 15 (April 2010): 6748-6752. https://doi.org/10.1073/pnas.0910827107. 
Canuto, Marcello A., Francisco Estrada-Belli, Thomas G. Garrison, Stephen D. Houston, Mary Jane Acuña, Milan Kováč, Damien Marken, et al. "Ancient Lowland Maya Complexity as Revealed by Airborne Laser Scanning of Northern Guatemala.” Science 361, no. 6409 (September 2018): 1-19. https://doi.org/10.1126/science.aau0137.

Chaudhari, Pramod R., Sanyogita Verma, B. K. Jha, and Dhiraj Kumar Singh. "Integrated Water-Less Management of Night Soil for Depollution of Water Resources and Water Conservation." Journal of Engineering Research and Applications 6, no. 5 (May 2016): 47-53.

Cockburn, T. A. "Infectious Diseases in Ancient Populations." Current Anthropology 12, no. 1 (1971): 45-62. https://doi.org/10.1086/201168.

Coggins, Clemency C. "A New Order and the Role of the Calendar: Some Characteristics of the Middle Classical Period at Tikal." In Maya Archaeology and Ethnohistory. Edited by N Hammond and G. R. Willey, 38-50. Austin, TX: University of Texas Press, 1979.

Cowgill, Ursula M. "An Agricultural Study of the Southern Maya Lowlands.” AmericanAnthropologist 64, no. 2 (1962): 273-286. https://doi.org/10.1525/aa.1962.64.2.02a00030.

Dahlin, Bruce H. "Climate and Prehistory on the Yucatan Peninsula." Climatic Change 5, no. 3 (September 1983): 245-263. https://doi.org/10.1007/BF02423521.

DeMenocal, Peter B. "Cultural Responses to Climate Change During the Late Holocene." Science 292, no. 5517 (April 2001): 667-673. https://doi.org/10.1126/science.1059287.

Diefendorf, Aaron F., and Erika J. Freimuth. "Extracting the Most from Terrestrial Plant-Derived nAlkyl Lipids and Their Carbon Isotopes from the Sedimentary Record: A Review." Organic Geochemistry 103 (January 2017): 1-21. https://doi.org/10.1016/j.orggeochem.2016.10.016.

Douglas, Peter M. J., Arthur A. Demarest, Mark Brenner, and Marcello A. Canuto. "Impacts of Climate Change on the Collapse of Lowland Maya Civilization." Annual Review of Earth and Planetary Sciences 44, no. 1 (June 2016): 613-645. https://doi.org/10.1146/annurev-earth-060115012512.

—., Mark Pagani, Marcello A. Canuto, Mark Brenner, David A. Hodell, Timothy I. Eglinton, and Jason H. Curtis. "Drought, Agricultural Adaptation, and Sociopolitical Collapse in the Maya Lowlands." Proceedings of the National Academy of Sciences 112, no. 18 (May 2015): 56075612. https://doi.org/10.1073/pnas.1419133112.

Dubois, Nathalie, and Jérémy Jacob. "Molecular Biomarkers of Anthropic Impacts in Natural Archives: A Review." Frontiers in Ecology and Evolution 4, (August 2016): 1-16. https://doi.org/10.3389/fevo.2016.00092.

Evans, Nicholas P., Thomas K. Bauska, Fernando Gázquez-Sánchez, Mark Brenner, Jason H. Curtis, and David A. Hodell. "Quantification of Drought during the Collapse of the Classic Maya Civilization.” Science 361, no. 6401 (August 2018): 498-501. https://doi.org/10.1126/science. aas 9871. 
Evans, Susan T. "The Productivity of Maguey Terrace Agriculture in Central Mexico during the Aztec Period." Latin American Antiquity 1, no. 2 (June 1990): 117-132. https://doi.org/10.23 $\underline{07 / 971983 .}$

Feakins, Sarah J. "Pollen-Corrected Leaf Wax D/H Reconstructions of Northeast African Hydrological Changes during the Late Miocene." Palaeogeography, Palaeoclimatology, Palaeoecology 374 (March 2013): 62-71. https://doi.org/10.1016/j.palaeo.2013.01.004.

Feakins, Sarah J., and Alex L. Sessions. "Controls on the D/H Ratios of Plant Leaf Waxes in an Arid Ecosystem." Geochimica et Cosmochimica Acta 74, no. 7 (April 2010): 2128-2141. https://doi.org/10.1016/j.gca.2010.01.016.

Fernández, Fabián G., Richard E. Terry, Takeshi Inomata, and Markus Eberl. “An Ethnoarchaeological Study of Chemical Residues in the Floors and Soils of Q'eqchi' Maya Houses at Las Pozas, Guatemala." Geoarchaeology 17, no. 6 (August 2002): 487-519. https://doi.org/10. 1002/gea.10026.

Ford, Anabel, and Ronald Nigh. "Origins of the Maya Forest Garden: Maya Resource Management." Journal of Ethnobiology 29, no. 2 (December 2009): 213-236. https://doi.org/10.2993/02780771-29.2.213.

Halperin, Christina T., Jean Baptiste Le Moine, and Enrique Pérez Zambrano. "Infrastructures of Moving Water at the Maya Site of Ucanal, Petén, Guatemala." Journal of Anthropological Archaeology 56 (December 2019): 101102. https://doi.org/10.1016/j.jaa.2019.101102.

Hansen, Richard D., Steven Bozarth, John Jacob, David Wahl and Thomas Schreiner. "Climatic and Environmental Variability in the Rise of Maya Civilization: A Preliminary Perspective from Northern Peten." Ancient Mesoamerica 13, no. 2 (July 2002): 273-295. https://doi.org /10.1017/S0956536102132093.

Haviland, William A. "Family Size, Prehistoric Population Estimates, and the Ancient Maya Society." American Antiquity 37, no. 1 (Jan 1972): 135-139. http://www.jstor.org/stable/278895.

Hodell, David A., Jason H. Curtis, and Mark Brenner. "Possible Role of Climate in the Collapse of Classic Maya Civilization.” Nature 375, no. 6530 (June 1995): 391-394. https://doi.org/10.10 $\underline{38 / 375391 \mathrm{a} 0 .}$.

. "Terminal Classic Drought in the Northern Maya Lowlands Inferred from Multiple Sediment Cores in Lake Chichancanab (Mexico)." Quaternary Science Reviews 24, no. 12-13(July 2005): 1413-1427. https://doi.org/10.1016/j.quascirev.2004.10.013.

Hoggarth, Julie A., Matthew Restall, James W. Wood, and Douglas J. Kennett. "Drought and Its Demographic Effects in the Maya Lowlands." Current Anthropology 58, no. 1 (February 2017): 82-113. https://doi.org/10.1086/690046.

Jobbová, Eva, Christophe Helmke, and Andrew Bevan. "Ritual Responses to Drought: An Examination of Ritual Expressions in Classic Maya Written Sources.” Human Ecology 46, no. 5 (October 
2018): 759-781. https://doi.org/10.1007/s10745-018-0019-6.

Jones-Engel, Lisa, Gregory A. Engel, Michael A. Schillaci, Aida Rompis, Artha Putra, Komang Gde Suaryana, Agustin Fuentes, et al. "Primate-to-Human Retroviral Transmission in Asia." Emerging Infectious Diseases 11, no. 7 (July 2005): 1028-1035. https://doi.org/10.32 01/eid1107.040957.

Kawa, Nicholas C., Yang Ding, Jo Kingsbury, Kori Goldberg, Forbes Lipschitz, Mitchell Scherer, and Fatuma Bonkiye. "Night Soil: Origins, Discontinuities, and Opportunities for Bridging the Metabolic Rift." Ethnobiology Letters 10, no. 1 (2019): 40-49. https://doi.org/10.14237/ebl.10. 1.2019.1351.

Keenan, Benjamin, et al. "Molecular Evidence for Human Population Change Associated with Climate Events in the Maya Lowlands." Quaternary Science Reviews. Forthcoming 2021.

Kennett, Douglas J., Sebastian F. M. Breitenbach, Valorie V. Aquino, Yemane Asmerom, Jaime Awe, Janes U. L. Baldini, Patrick Bartlein, et al. "Development and Disintegration of Maya Political Systems in Response to Climate Change," Science 338, no. 6108 (November 2012): 788-791. https://doi.org/10.1126/science.1226299.

Lange de, Elvira S., Dirk Balmer, Brigitte Mauch-Mani, and Ted C. J. Turlings. "Insect and Pathogen Attack and Resistance in Maize and Its Wild Ancestors, the Teosintes." New Phytologist 204, no. 2 (2014): 329-341. https://doi.org/10.1111/nph.13005.

Leyden, Barbara W. "Man and Climate in the Maya Lowlands." Quaternary Research 28, no. 3 (November 1987): 407-414. https://doi.org/10.1016/0033-5894(87)90007-X.

- "Pollen Evidence for Climatic Variability and Cultural Disturbance in the Maya Lowlands." Ancient Mesoamerica 13, no. 1 (January 2002): 85-101. https://doi.org/10.1017/ $\underline{\text { S0956536102131099. }}$

Li, Wendong, Zhengli Shi, Meng Yu, Wuze Ren, Craig Smith, Jonathan H. Epstein, Hanzhong Wang, et al. "Bats Are Natural Reservoirs of SARS-like Coronaviruses." Science, New Series 310, no. 5748 (October 2005): 676-679. http://www.jstor.org/stable/3842715.

Lucero, Lisa J., Joel D. Gunn, and Vernon L. Scarborough. "Climate Change and Classic Maya Water Management.” Water 3, no. 2 (December 2011): 479-494. https://doi.org/10.3390/w3020479.

Luzzadder-Beach, Sheryl, Timothy Beach, Scott Hutson, and Samantha Krause. "Sky-Earth, Lake-Sea: Climate and Water in Maya History and Landscape.” Antiquity 90, no. 350 (April 2016): 426442. https://doi.org/10.15184/aqy.2016.38.

Magnoni, Aline. "Population Estimates at the Ancient Maya City of Chunchucmil, Yucatán, Mexico." In Digital Discovery: Exploring New Frontiers in Human Heritage. CAA2006. Computer Applications and Quantitative Methods in Archaeology. Proceedings of the 34th Conference, 159-166. Edited by Clark, J.T. and E.M. Hagemeister. Budapest: Archaeolingua, 2006. 
Magrin, Graciela O., José A. Marengo, Jean-Philliipe Boulander, Marco S. Buckeridge, Edwin Castellanos, German Poveda, Fabio R. Scarano, et al. "Central and South America." In Climate Change 2014: Impacts, Adaptation and Vulnerability. Part B: Regional Aspects. Contribution of Working Group II to the Fifth Assessment Report of the Intergovernmental Panel on Climate Change. Edited by V.R. Barros et al., 1499-1566. Cambridge: Cambridge University Press, 2014. https://doi.org/10.5860/choice.45-5008.

McDermott, Frank. "Palaeo-Climate Reconstruction from Stable Isotope Variations in Speleothems: A Review." Quaternary Science Reviews 23, no. 7-8 (April 2004): 901-918. https://doi.org/10.1016/j.quascirev.2003.06.021.

Medina-Elizalde, Martín, Stephen J. Burns, David W. Lea, Yemane Asmerom, Lucien von Gunten, Victor Polyak, Mathias Vuille, and Ambarish Karmalkar. "High Resolution Stalagmite Climate Record from the Yucatán Peninsula Spanning the Maya Terminal Classic Period." Earth and Planetary Science Letters 298, 1-2 (September 2010): 255-262. https://doi.org/10.1016 jj.eps1.2010.08.016.

Moholy-Nagy, Hattula. "Utilization of Pomocea Snails at Tikal, Guatemala." American Antiquity 43, no. 1 (January 1978): 65-73.

Mouinga-Ondeme, Augustin, Mélanie Caron, Dieudonné Nkoghé, Paul Telfer, Preston Marx, Ali Saïb, Eric Leroy, Jean-Paul Gonzales, Antoine Gessain, and Mirdad Kazanji. "Cross-Species Transmission of Simian Foamy Virus to Humans in Rural Gabon, Central Africa." Journal of Virology 86, no. 2 (January 2012): 1255-1260. https://doi.org/10.1128/jvi.06016-11.

Mueller Andreas D., et al. "Recovery of the Forest Ecosystem in the Tropical Lowlands of Northern Guatemala after Disintegration of Classic Maya Polities." Geology 38, no. 6 (June 2010): 523526. https://doi.org/10.1130/G30797.1.

Niedermeyer, E., Brian McKee Chase, and Andreas Mulch. "Southwestern African Climate Change during Heinrich Stadial 1 Inferred from Plant Wax $\delta 13 \mathrm{C}$ and $\Delta \mathrm{D}$ from Rock Hyrax Middens," Quaternary International 404 (June 2016): 202. https://doi.org/10.1016/j.quaint.2015.08.181.

Nooren, Kees, et al. "Climate Impact on the Development of Pre-Classic Maya Civilization." Climate of the Past Discussions 14, no. 8 (August 2018): 1253-1273. https://doi.org/10.5194/cp-201815.

Oglesby, Robert J., Thomas L. Sever, William Saturno, David J. Erikson III, and Jayamthi Srikishen. "Collapse of the Maya: Could Deforestation Have Contributed?" Journal of Geophysical Research Atmospheres 115, no. 12 (June 2010): 1-10. https://doi.org/10.1029/2009JD011942.

Orlove, Ben. "Human Adaptation to Climate Change: A Review of Three Historical Cases and Some General Perspectives." Environmental Science and Policy 8, no. 6 (December 2005): 589600. https://doi.org/10.1016/j.envsci.2005.06.009.

Rosenmeier, Michael F., David A. Hodell, Mark Brenner, Jason H. Curtis, and Thomas P. Guilderson 
"A 4000-Year Lacustrine Record of Environmental Change in the Southern Maya Lowlands, Petén, Guatemala." Quaternary Research 57, no. 2 (Febuary 2002):183-190. https://doi.org/10. 1006/qres.2001.2305.

Sachse, Dirk, Isabelle Billault, Gabriel J. Bowen, Yoshito Chikaraishi, Todd E. Dawson, Sarah J. Feakins, Katherin H. Freeman, et al. "Molecular Paleohydrology: Interpreting the HydrogenIsotopic Composition of Lipid Biomarkers from Photosynthesizing Organisms." Annual Review of Earth and Planetary Sciences 40, no. 1 (May 2012): 221-249. https://doi.org/10.114 6/annurev-earth-042711-105535.

Schüpbach, Simon, Torben Kirchgeorg, Daniele Colombaroli, Giorgia Beffa, Marta Radaelli, Natalie M. Kehrwald, and Carlo Barbante. "Combining Charcoal Sediment and Molecular Markers to Infer a Holocene Fire History in the Maya Lowlands of Petén, Guatemala." Quaternary Science Reviews 115, no.1 (May 2015): 123-131. https://doi.org/10.1016/j.quascirev.2015.03.004.

Sharer, Robert J., and Loa P. Traxler. The Ancient Maya. Sixth Edition. Stanford, California: Stanford University Press, 2006.

Shaw, Justine M. "Climate Change and Deforestation: Implications for the Maya Collapse." Ancient Mesoamerica 14, no. 1 (January 2003): 157-167. https://doi.org/10.1017/S0956536103132063.

Santley, Robert S., Thomas W Killion, and Mark T Lycett. "On the Maya Collapse." Journal of Anthropological Research 42, no. 2 (1Summer 986): 123-159. http://www.jstor.org/stable/3630485.

Song, Youhong, Colin Birch, Shanshan Qu, Al Dohert, and Jim Hanan. "Analysis and Modelling of the Effects of Water Stress on Maize Growth and Yield in Dryland Conditions." Plant Production Science 13, no. 2 (2010): 199-208. https://doi.org/10.1626/pps.13.199.

Sweetwood, Ryan V., Richard Terry, Timothy Paul Beach, and Bruce H. Dahlin. "The Maya Footprint: Soil Resources of Chunchucmil, Yucatán, Mexico.” Soil Science Society of America Journal 73, no. 4 (July 2009): 1209-1220. https://doi.org/10.2136/sssaj2008.0262.

Tans, Pieter, and Ralph Keeling. "Trends in Atmospheric Carbon Dioxide." Global Monitoring Laboratory. Accessed March 30, 2020. www.esrl.noaa.gov/gmd/ccgg/trends/.

Turner B. L., and Jeremy A. Sabloff. "Classic Period Collapse of the Central Maya Lowlands: Insights about Human-Environment Relationships for Sustainability." Proceedings of the National Academy of Sciences of the United States of America 109, no. 35 (August 2012): 13908-13914. https://doi.org/10.1073/pnas.1210106109.

Van Tuerenhout, Dirk, and John Weeks. The Aztecs: New Perspectives. Santa Barbara, California: ABC-CLIO, 2005.

Wang, Ming, Meiying Yan, and Huifang Xu. "SARS-CoV Infection in a Restaurant from Palm Civet." 
Emerging Infectious Diseases 11, no. 12 (December 2005): 1860-1865. https://doi.org/10. 3201/eid1112.041293.

Warinner, Christina, Nelly Robles García, Ronald Spores, and Noreen Tuross. "Disease, Demography, and Diet in Early Colonial New Spain: Investigation of a Sixteenth-Century Mixtec Cemetery at Teposcolula Yucundaa." Latin American Antiquity 23, no. 4 (December 2012): 467-489. https://doi.org/10.7183/1045-6635.23.4.467.

Warkentin, Benno. Footprints in the Soil: People and Ideas in Soil History. Burlington: Elsevier Science, 2006.

Weiss H., M. A. Courty, W. Wetterstrom, F. Guichard, L. Senior, R. Meadow, and A. Curnow. "The Genesis and Collapse of Third Millennium North Mesopotamian Civilization." Science 261, no. 5124 (1993): 995-1004. https://doi.org/10.1126/science.261.5124.995.

White, A. J., Lora R. Stevens, Varenka Lorenzi, Samuel E. Munoz, Carl P. Lipo, and Sissel Schroeder. "An Evaluation of Fecal Stanols as Indicators of Population Change at Cahokia, Illinois." Journal of Archaeological Science 93 (May 2018): 129-134. https://doi.org/https://doi.org/10. 1016/j.jas.2018.03.009.

Wilbur, Alicia Kay, and Jane Ellen Buikstra. "Patterns of Tuberculosis in the Americas - How Can Modern Biomedicine Inform the Ancient Past?" Memorias Do Instituto Oswaldo Cruz 101, no. 2 (December 2006): 59-66. https://doi.org/10.1590/S0074-02762006001000011.

Wilken, Gene C. Good Farmers: Traditional Agricultural Resource Management in Mexico and Central America. Berkley: University of California Press, 1990.

Wood, James W. "A Theory of Preindustrial Population Dynamics: Demography, Economy, and WellBeing in Malthusian Systems." Current Anthropology 39, no. 1 (February 1998): 99-135. https://doi.org/10.1086/204700.

Wright, Lori E. "Biological Perspectives on the Collapse of the Pasion Maya." Ancient Mesoamerica 8, no. 2 (Fall 1997): 267-273. https://doi.org/10.1017/S0956536100001723.

Wright, Lori E., and Christine D. White. "Human Biology in the Classic Maya Collapse: Evidence from Paleopathology and Paleodiet.” Journal of World Prehistory 10, no. 2 (June 1996): 147-198.

Wright, Lori E., and Francisco Chew. "Porotic Hyperostosis and Paleoepidemiology: A Forensic Perspective on Anemia among the Ancient Maya." American Anthropologist 100, no. 4 (December 1998): 924-939. https://doi.org/10.1525/aa.1998.100.4.924.

Zocatelli, Renata, Marlène Lavrieux, Typhaine Guillemot, Léo Chassiot, Claude Le Milbeau, and Jérémy Jacob. "Fecal Biomarker Imprints as Indicators of Past Human Land Uses: Source Distinction and Preservation Potential in Archaeological and Natural Archives." Journal of Archaeological Science 81 (May 2017): 79-89. https://doi.org/10.1016/j.jas.2017.03.010. 